\title{
Reflections of Urban Transformation on Horizontal City Landscape and Household: Adana Çukurova District Municipality Houses
}

\author{
Tülay Öcal \\ Department of Geography, Faculty of Science and Letters, Hatay Mustafa Kemal University, Antakya, Turkey \\ Email: tulayocal5101@gmail.com
}

How to cite this paper: Öcal, T. (2019). Reflections of Urban Transformation on Horizontal City Landscape and Household: Adana Çukurova District Municipality Houses. Current Urban Studies, 7, 517-538. https://doi.org/10.4236/cus.2019.74026

Received: August 21, 2019

Accepted: October 21, 2019

Published: October 24, 2019

Copyright $\odot 2019$ by author(s) and Scientific Research Publishing Inc. This work is licensed under the Creative Commons Attribution International License (CC BY 4.0).

http://creativecommons.org/licenses/by/4.0/

(c) (i) Open Access

\begin{abstract}
In Turkey, urban planning works are staying on the agenda with the decisions made at the central level. Because these urban works reached their purpose in some of our cities, whereas these urban works became a big problem of our society. Urban transformation works covering population and settlement problems of human geography will be examined as urban geography and population problems and recommendations for solution will be made. Within the scope of this study, spatial and social changes on the city made by houses that are going to build over the Adana Çukurova District Municipality Houses and single-detached houses will be discussed and results obtained through interviews will be interpreted with a geographic point of view. Allocation of apartments according to plot size and the property owners will be indebted are the greatest concerns of property owners. The problems that will arise from the big identity change caused by vertical growth with the construction in the Municipality Houses will be analyzed and the expectations and concerns of people living in Municipality Houses will be determined.
\end{abstract}

\section{Keywords}

Effect of Planning to Space, Urban Transformation in Çukurova, Municipality's Attitude towards Planning, Property Owners' Attitude towards Transformation

\section{Introduction}

Although a certain distance has been taken in the housing production practices planned to eliminate the housing deficit caused by rural to urban migration and rapid population growth, mass housing production realized by both the public 
and private sectors has remained inadequate quantitatively and qualitatively (Özsoy, 2012: p. 42). Therefore, it has become inevitable to produce a drastic solution by the government. For this purpose, the Mass Housing Fund was initiated in our country in 1984 with the Mass Housing Law numbered 2985. For effective use of the Fund, a Mass Housing and State Partnership Administration was established. In 1990, the Administration was divided into two separate institutions, namely the Masses Housing Administration (TOKİ) and the State Partnership Administration. TOKI has started a housing mobilization through mass housing production especially after 2000 and has completed 500 thousand houses until 2011. However, considering the fact that TOKI meets only $10 \%$ $15 \%$ of the housing needs of our country, it is clear how serious the housing deficit is (Koca \& Karadeniz, 2014). Today, in cities where TOKI housing is insufficient, housing deficit is being tried to be solved by introducing urban transformation practices. Urban transformation is the reorganization of unhealthy structured housing which is vulnerable to disasters and urban risks, which have inadequate and unqualified infrastructure and which were built in legal or illegal zoning places in accordance with the new zoning plan data. Procedures such as legally determining the implementation tools, how to implement the zoning plan prepared and the registration of these to the title deeds also constitute the urban transformation process (Akınc1, 2007: p. 44; Aydınlı \& Kaya, 2013). The success of the plan in urban transformation requires good city planning.

There are no mechanisms for the participation of all segments of society in the process of planning, implementation and structuring. For the first time, projects where local rights holders are involved in decision-making have been encountered (Göksu, 2003: p. 273). On the other hand, there were situations where local participation was almost completely ignored, expropriation processes enabled the acquisition of property by third parties and the owners were taken out of the picture with concepts such as "urgent expropriation". In addition to the examples where the owners stayed in the same area, there were also times where owners were moved to other areas. In particular, a different understanding has come to being by the effective involvement of Mass Housing Administration implementation in the urban transformation process with the powers granted by the Mass Housing Law numbered 5162 dated 05.05.2004 and the Law on General Staff and Procedures (Sırma \& Çaçtas Ceylan, 2009). In general, a settlement in accordance with the urban rights perspective should be basically "habitable", "right" and "sustainable". The means to achieve these purposive principles are civil engagement, enablement and multi-actor governance (Haziran, 1996: pp. 81-88; Tekeli, 2001: pp. 160-164). The deterioration of environmental qualities, demolition and destruction of the city, unqualified designs that do not take into account the needs, culture and expectations of the inhabitants, etc., impact the habitability of the settlement (Arslan, 2014). Habitability in cities means an indispensable livable environment for the city people. Developed countries established this environment after the industrial revolution and continue to live in 
this environment. Developing countries live in unhealthy environments in cities, industrial areas and shanty towns and have been making new plans to change these. In our country, which is one of the developing countries, with the urbanization, housing construction has accelerated through cooperatives.

Today, world countries are realizing housing construction in their countries by using different approaches in urban planning. Traditionally, tools such as direct government interventions using regulatory, zoning, development control, procurement and procurement programs of select area and development rights have been the dominant view in planning practice (Wang et al., 2010; Rydin, 1993; Heimlich \& Anderson, 2001). However, the effectiveness of these tools has remained a critical concern amongst planners and economists. Main criticisms claim relatively low efficiency and effectiveness, unfair results and significant transaction costs (Fischel, 2000; Rydin, 1998; Pogodzinski \& Sass, 1990; Mills, 1989; Nelson, 1977; Shahab et al., 2019). In our country, development and development activities are mostly carried out by direct state interventions. Zoning sites are determined by the state and through municipalities. When these areas are opened for development, the fertility and use of the soil remains second place. Municipalities allow the construction companies to construct buildings in the areas that were open for development. The buildings constructed by the state and the municipalities are done in two ways. Renewal practices have been realized particularly in the areas opened for development and in the old and worn shanty housing areas. Shanty housing areas are the distorted urbanization done on state treasure lands due to rapid migration to cities due to the increase in population after 1950 . The metropolitan municipalities made zoning amnesties due to election concerns and gave zoning to the shanty houses and legalized the houses these areas. These areas are today's worn-out areas in the city centers.

In developed and developing countries, such worn out areas emerge and each country develops projects through its own internal dynamics. The Transferable Development Rights (TDR) approach has attracted great attention in many developed and developing countries (Janssen-Jansen et al., 2008; Spaans, Janssen-Jansen, \& van der Veen, 2011; Wang, Tao, Wang, \& Su, 2010) and was applied to discuss different land conservation/development objectives (Shahab et al., 2018). The Housing Development Administration of Turkey has made strides in public housing apartments since 2004 and made people who are in need homeowners by establishing TOKI. The TOKI project has been combined with urban transformation to create a livable environment by making unhealthy settlements healthy in cities. Since the migration from rural to urban areas lasted for years, shanty housing areas around the city became uninhabitable. Therefore, TOKI projects became unsufficient in big cities. As of 2012, private companies were also given the right to construct in the urban transformation areas. However, since the property owners were given apartments based on the size of their plots, the property owners and the contractors began to experience problems. In 
our country, the urban transformation projects that are carried out with the cooperation of the Ministry of Environment and Urbanization and the Municipalities mostly cover shanty housing areas without zoning. In cities where mass housing is inadequate, the urban transformation is transferred to the contractors and private companies carry out the transformation. There are problems in single-attached houses which have small plots but also have three to four floors. For example, only one apartment is given to a $100 \mathrm{~m}^{2}$ plot where four families live. This leaves the homeowners in a difficult position in Turkey's conditions. There is injustice between the homeowners and landowners, and the contractors and the ones who are doing the TOKI projects. Homeowners and landowners have been complaining about this since 2004 .

Although the interest in the subject of urban transformation issues has been going on in Turkey, fears and concerns of the population in the settlements located within the urban transformation project continues. Within the scope of the urban transformation project in Sarıgöl Neighborhood, low-rise houses with yards were demolished and 16-storey giant blocks were built. It is clear that the move of a large number of foreigners to these blocks will radically change neighborhood relationships in the neighborhood. The distinctive gypsy identity of the ŞenNeighborhood will be replaced by a cosmopolitan urban identity. Urban Transformation Project will be transformed into a process of displacement and old problems will be revived in the nearest neighborhoods (Hardal, 2014; Kılıç \& Hardal, 2015) because forcing the people who owned houses under really difficult financial situations to integrate into an apartment life or to force them to move to a totally new place and form a new neighborhood will not solve the problems but will only postpone them. For example, similar problems have been seen in Belediye Evleri (Municipality Houses) urban transformation project in Adana's Çukurova district. These problems are waiting to be solved. Therefore, it is necessary to examine the problems and expectations of the population in the neighborhood with a geographical approach.

\section{Purpose and Method}

The aim of this study is to examine the concerns and expectations of the people living in the Belediye Evleri neighborhood, where Çukurova Central District Municipality wants to establish new settlements through urban transformation of the worn settlements, with an urban geography perspective. Another purpose of the study is to determine whether horizontal urban fabric or vertical urban fabric is suitable for habitation by conducting interviews and administering surveys to the people living in the neighborhood. Learning from the neighborhood residents whether or not the municipality informed them about the urban transformation is another purpose of the study. The study also aims to reveal whether or not residents support urban transformation. The biggest concerns of the property owners are that they will give apartments based on the plot size and that they need to get loans. The study will analyze the problems that will rise 
from identity change based on vertical growth in the Belediye Evleri neighborhood.

Municipal Housing Neighborhood Urban Transformation Project is extremely vital in terms of informing the residents about the project, cooperating with them, ensuring the participation of the residents and the successful completion of the project. The main purpose of this study is to examine the already started Municipal Housing Neighborhood Urban Transformation Project from a geographical point of view and to put forth the population, social and cultural changes of the urban area and the perspectives of the people who will be affected by the changes in this urban area. This study is very important in terms of minimizing the plans made at the desk without asking the opinions of the people living there. For this purpose, surveys were developed and administered to the neighborhood residents who will be affected by the project, and interviews were conducted with them. The surveys will ask items to learn residents' views on demographic, economic, ownership and urban transformation, their perspectives on urban transformation, and their expectations and concerns about the project. Structured Likert surveys were applied to 200 people living in mass housing and to 200 people living in detached houses by using mutual interview questionnaire technique. Hence, surveys were administered to a total of 400 people. Developed to determine Municipal Houses Neighborhood residents' demographic structure, ownership status, income levels, reasons for living in the neighborhood, the number of individuals per apartment, satisfaction with the current neighborhoods and houses, and their views, expectations and approaches on urban transformation the questionnaire form was made up of three sections. After the questionnaire was applied, the data were analyzed by SPSS24 program with statistical methods and frequency analysis. The results were interpreted in relation to the social and economic characteristics of the neighborhood.

\section{Location of Çukurova District's Belediye Evleri Neighborhood}

According to Öcal and Çalışkan (2017: p. 150), Adana is a city established between 15 - 130 m elevation step on the banks of Seyhan River in the center of Çukurova, which is the largest base level plain of the Eastern Mediterranean Basin, between the Central Taurus and Amanos. Adana city is made up of Çukurova, Sarıçam, Seyhan, Yüreğir and Karaisalı Central Districts (Figure 1).

The city was established in Seyhan's Köprübaşı, in the lower parts of the plain, where it was convenient to hold a castle before the river spread and expanded. As a result of intensive agricultural activities in the plain, the city's industry and trade developed, and thanks to a busy transportation network, it developed and attracted population and caused the increase of slums. However, our study area, the urban transformation area of Çukurova Municipal Houses Neighborhood urban transformation areas is not a slum area, and consists of two-, three- and 


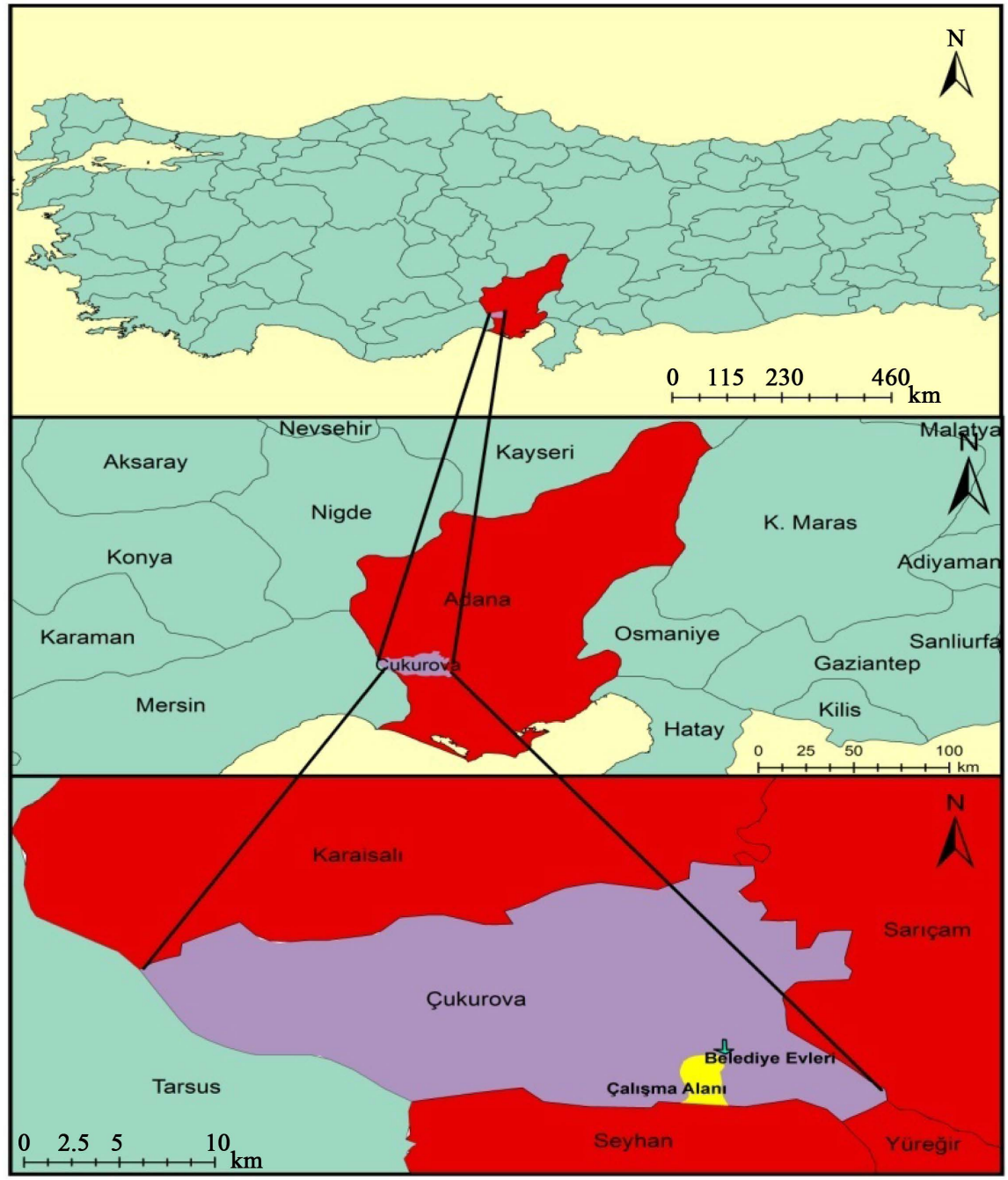

Figure 1. Location map of belediye evleri neighborhood. Third part: Study field.

four-storey housing units built by the Adana Metropolitan Municipality. Moreover, there are detached one and two storey houses in the zoning plan area within the boundaries of the Belediye Evleri neighborhood.

\section{4. Çukurova Belediye Evleri Neighborhood and Urban Transformation Project}

In Çukurova District's Belediye Evleri, there are two-, three- and four-storey buildings, which are suitable for lower income people, produced by the cooperatives and municipal public housing system between 1988-1989. These houses are made of $1440 \mathrm{~m}^{2}$ town houses (32 flats), $28,660 \mathrm{~m}^{2}$ two-storey town houses ( 873 flats), $56 \mathrm{~m}^{2}$ three-storey townhouses (349 flats), 14,264 $\mathrm{m}^{2}$ four storey townhouses (1138 flats), 1537 one-story detached houses and 3526 two-storey detached houses, 728,108 $\mathrm{m}^{2}$ duplex houses (917 independent flats). Amongst these buildings, there are home businesses in $60 \mathrm{~m}^{2}$ town houses, 320 business in 36 apartments, 136 business in the first two storeys of the $64 \mathrm{~m}^{2}$ four-storey town 
houses. Hence, Belediye Evleri is made of a total of 2816 apartments and 7291 independent flats (Table 1, Photo 1). These data are the updated information on the number of buildings and business in Belediye Evleri Neighborhood. The population of Belediye Evleri Neighborhood in 2018 was 57,022.

The mass housing and home plans of the Çukurova Belediye Evleri Neighborhood were designed by the architects of Adana Metropolitan Municipality, and is made up of detached houses controlled by the workers of Adana Metropolitan Municipality during its construction phase. Considering all the urban transformation sites in Turkey, this specific urban transformation site leaves question marks in people's heads. While the study emphasizes these issues, it is not possible for the residents not to think about them. Because this place consists of detached houses opened to zoning by the Metropolitan Municipality but at the same time this place was designed and shown to people as zoned areas in time. While some of the neighborhood consists of mass housing units, it was also open to detached houses as zoned areas. The planning and inspections of these detached houses were approved by the metropolitan municipality of the time as licensed buildings. Today, Çukurova Municipality is planning to give a new look to this area by constructing smart buildings and developing landscaping consisting of 15 - 20 storeys in this area (Figure 2, Photo 2).

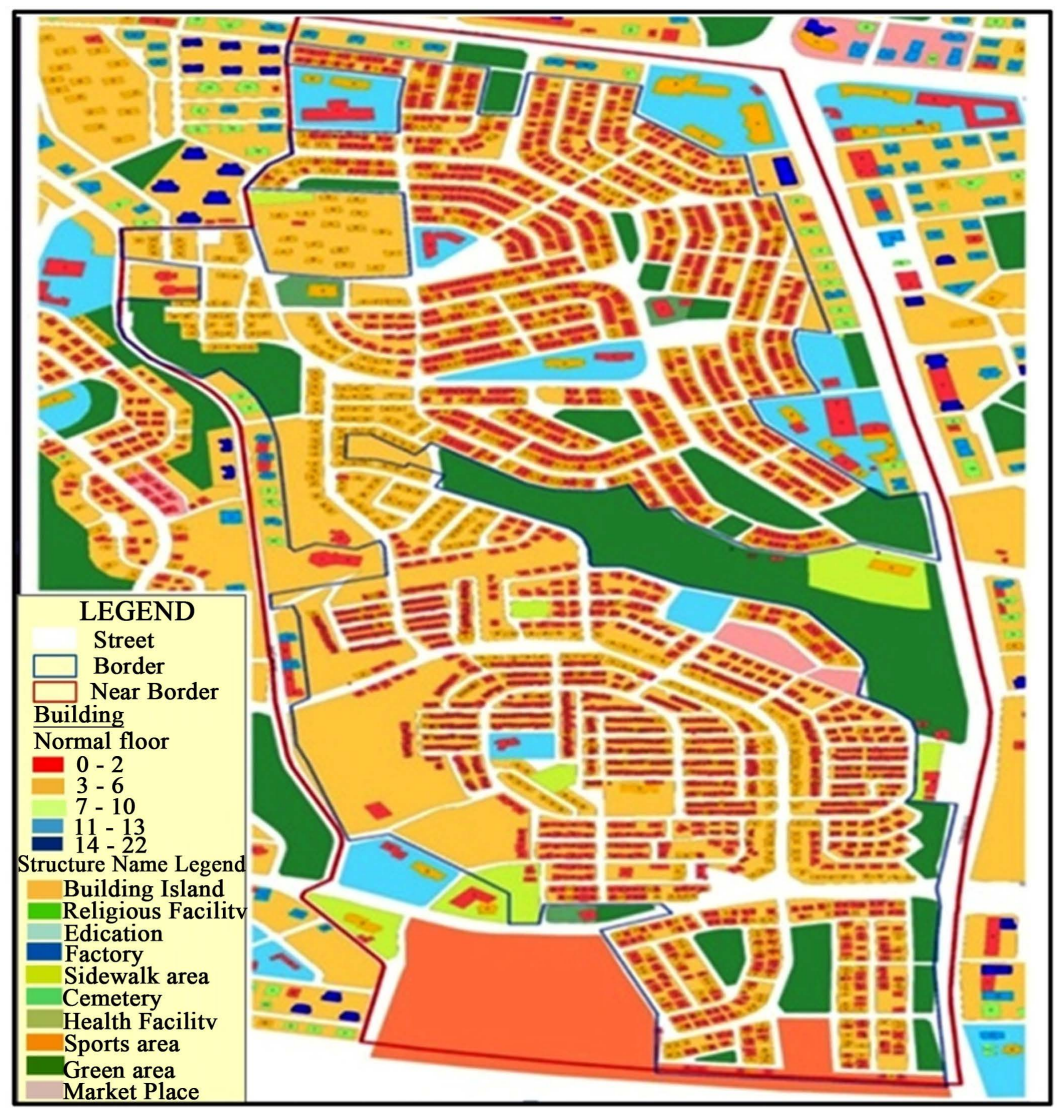

Figure 2. The zoning plan of the urban transformation project that will be done in the Belediye Evleri Neighborhood by the Çukurova District. 


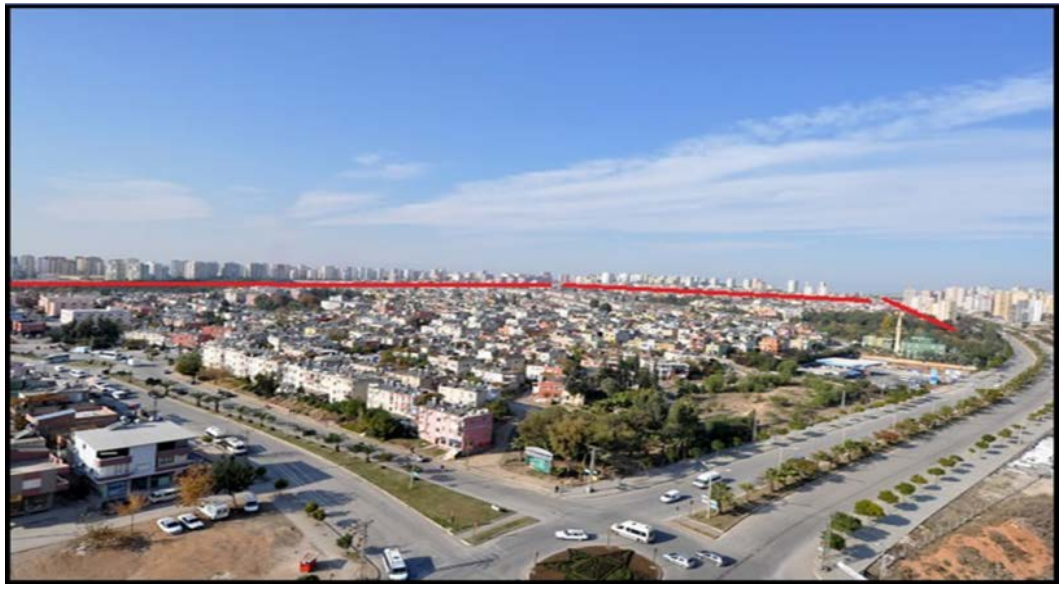

Photo 1. Entrance to Belediye Evleri neighborhood and the surrounding blocks (Source: http://yenibelediyeevleri.com/).

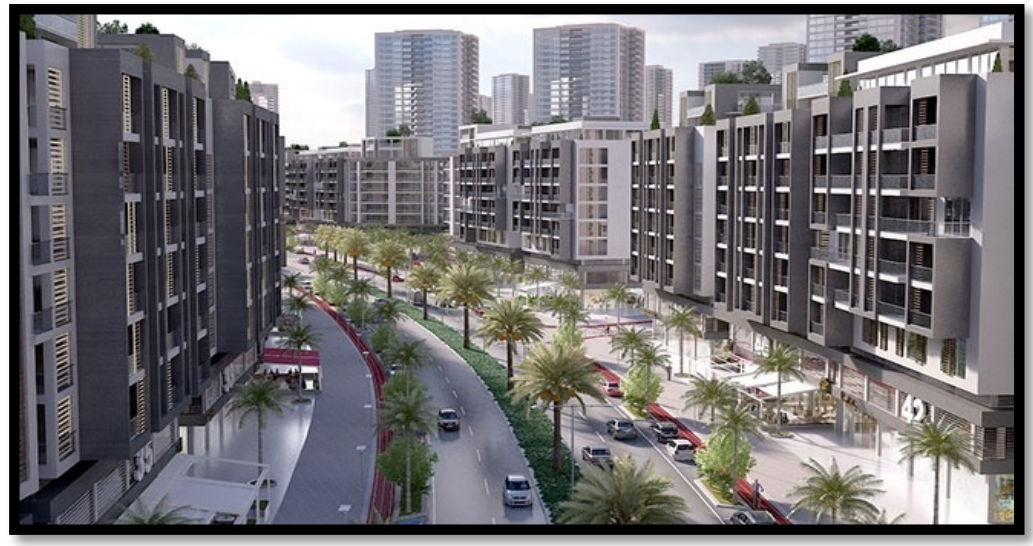

Photo 2. Belediye Evleri smart building blocks planned by the Çukurova Municipality. (Source:

http://www.refleksgazetesi.com/cukurova-daki-kentsel-donusum-jeoloji-muhendislerinin -kadrajinda/4888).

Table 1. Updated Information on the number of buildings and flats in Belediye Evleri.

\begin{tabular}{ccc}
\hline Type Name & Building Number & Independent Flat Number \\
\hline $108 \mathrm{~m}^{2}$ Duplex House & 728 & 917 \\
$40 \mathrm{~m}^{2}$ two town houses & 14 & 32 \\
$60 \mathrm{~m}^{2}$ two-storey two town houses & 233 & 658 \\
$60 \mathrm{~m}^{2}$ two-storey town houses & 53 & 215 \\
$60 \mathrm{~m}^{2}$ three-storey town houses & 56 & 349 \\
$60 \mathrm{~m}^{2}$ Townhouse + business & 36 & 320 \\
$64 \mathrm{~m}^{2}$ four-storey town houses & 142 & 1138 \\
$64 \mathrm{~m}^{2}$ four story town houses + two stores & 17 & 136 \\
Detached houses & 1537 & 3526 \\
General Total & 2816 & 7291 \\
\hline
\end{tabular}

Source: http://yenibelediyeevleri.com/. 
Residents of the Municipality Houses have been simply living in their homes to this day and expecting to benefit from municipal services but they have been hearing about urban transformation for the last three years. Belediye Evleri residents were waiting for the completion of the landscaping and the lack of infrastructure in their neighborhood. In fact, they do not look at the subject of urban transformation positively. As we mentioned earlier, the Belediye Evleri Neighborhood is composed of two parts. One of them consists of housing units built by the Adana Metropolitan Municipality between 1988 and 1989 for the purpose of providing homes for low-income people. These are made up of two, three and four storey blocks. Since the residents have a low income, they were able to pay for these houses only in $10-15$ years, and since they cannot maintain these housing units, the houses have been worn and neglected (Photo 3 ).

The detached houses in the second section are located in the zoned area to the east of the housing units of Belediye Evleri Neighborhood. They consist of one and two storey houses and duplex houses. These houses are not worn out like the mass houses in the other section and are cared for by their owners (Photo 4).

The road and street system of these detached houses has not been landscaped by the municipality and they are intended to be demolished together with the

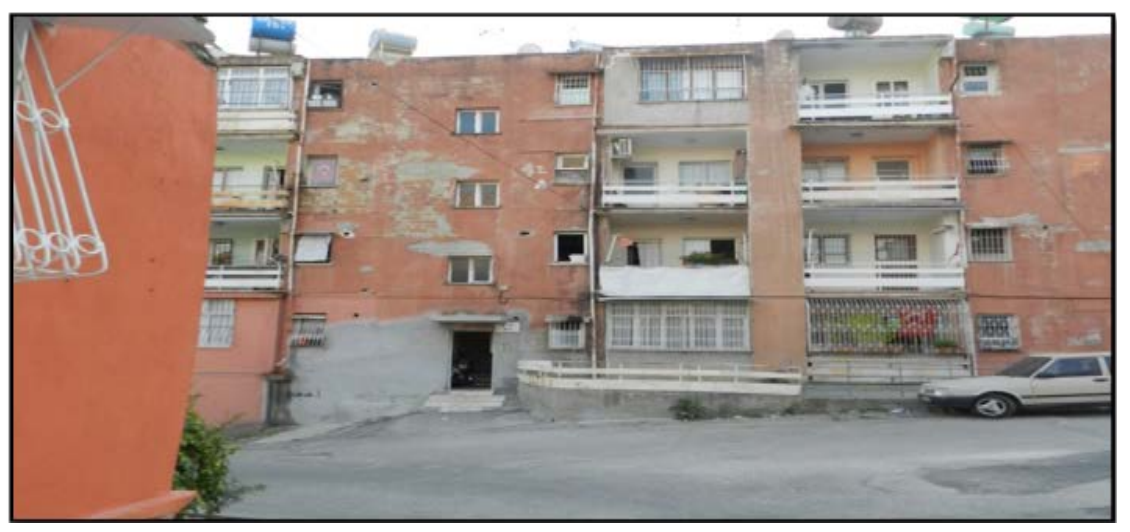

Photo 3. Present day four storey buildings in Belediye Evleri neighborhood.

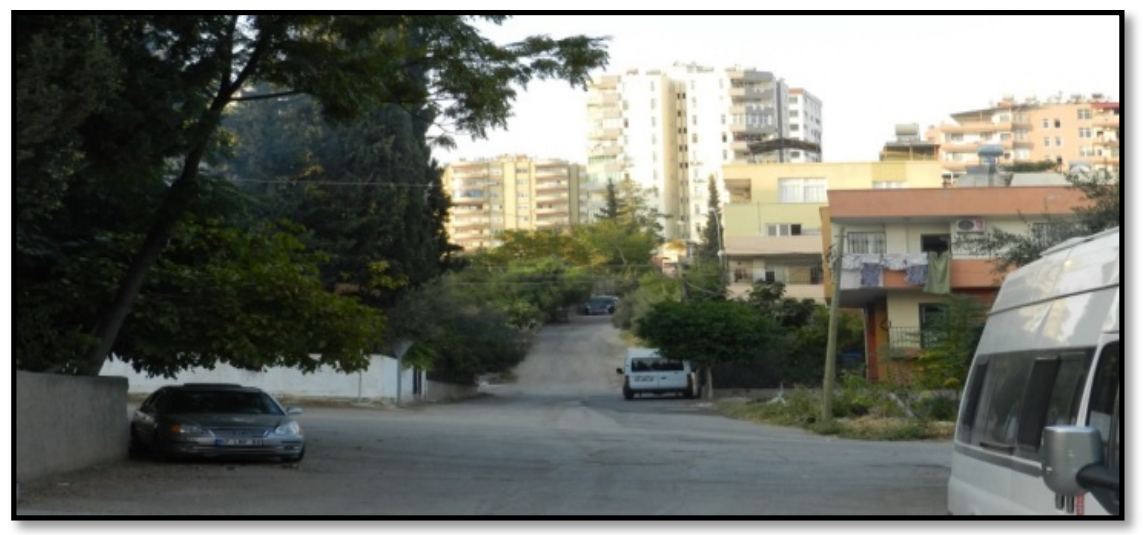

Photo 4. Detached houses in the Belediye Evleri neighborhood and the apartment blocks around them. 
housing units in the other section. The residents of these houses do not want their houses demolished and apartments to be built in their places. In the interviews, these people stated that they would prefer to live in detached houses instead of apartments. The detached houses in this section of the Belediye Evleri Neighborhood is different than the other urban transformation areas of Turkey because the houses are zoned and their architectural drawings were completed years ago. The plans of these buildings were made according to approved projects, necessary materials were used in the construction of the buildings. Furthermore, these houses were built under supervision to be earthquake-resistant houses.

\section{Attraction Center Belediye Evleri Neighborhood}

Municipal Houses were located outside the city when the houses of the neighborhood were delivered to their current owners between 1988-1989. Public buses were only working here at certain times. This place has become a center of attraction with the filling of houses in time and especially with the apartments. While Çukurova was previously located within the boundaries of Adana's Seyhan Central District, it was gradually separated and became its own central district. With this separation, Belediye Evleri Neighborhood became part of the Çukurova Central District (Figure 3).

It is not possible to find areas with detached houses and low-rise buildings within the borders of Çukurova Municipality. New buildings, previously opened for reconstruction for duplex buildings, were demolished and a building complex area was created for the construction of a 20-storey apartment building. Although this field consists of the most fertile alluvial soil of the land in Turkey, it became the city's center of attraction, and its value is increasing. Even though the houses in the Belediye Evleri Neighborhood are referred to as worn out and

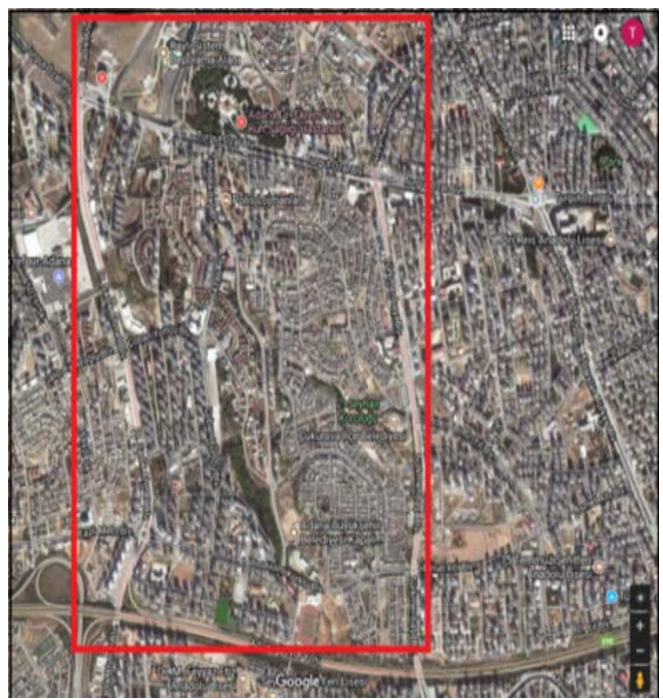

Figure 3. Çukurova central district's Belediye Evleri neighborhood's view from the Google Earth Map. 
necessary to be demolished, the question of why the Çukurova Municipality chose this place for urban transformation comes to mind after seeing the building complexes and apartment buildings around it. The residents stated that they have been asking the same questions to themselves. While the rents around here are around 400 - 500 Turkish Liras, the rents on the surrounding building complexes are starting from 1000 Turkish Liras. The mass houses, detached houses and duplex houses within the Belediye Evleri Neighborhood are now surrounded by building complexes and apartments (Photos 5-7).

Çukurova Municipality states that there is a lot of deterioration in the housing units of Belediye Evleri Neighborhood and that it is located close to the earthquake zone and furthermore states that it needs to be demolished and urban transformation should take place. The city of Adana is surrounded by the Eastern Anatolian Fault zone in the east and the Ecemiş fault in the west and northwest. One of Turkey's biggest fault zones, the East Anatolian fault and Ecemiş fault is today still considered active faults that continue their activity. The Urban Transformation area is considered as a second degree earthquake zone (http://yenibelediyeevleri.com/) (Figure 4).

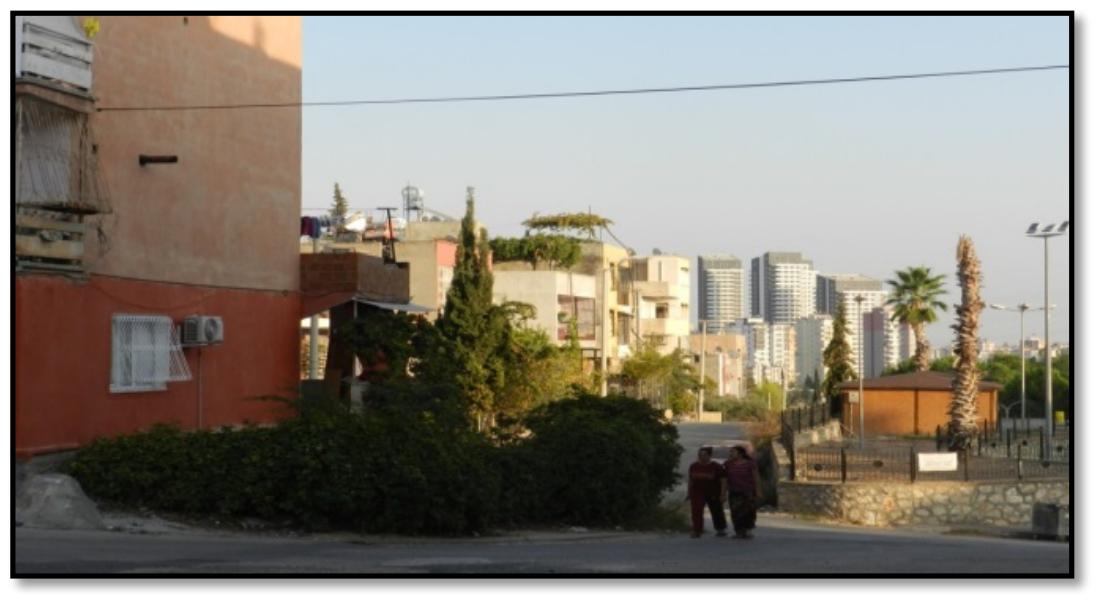

Photo 5. The building complexes surrounding the two storey buildings of Belediye Evleri.

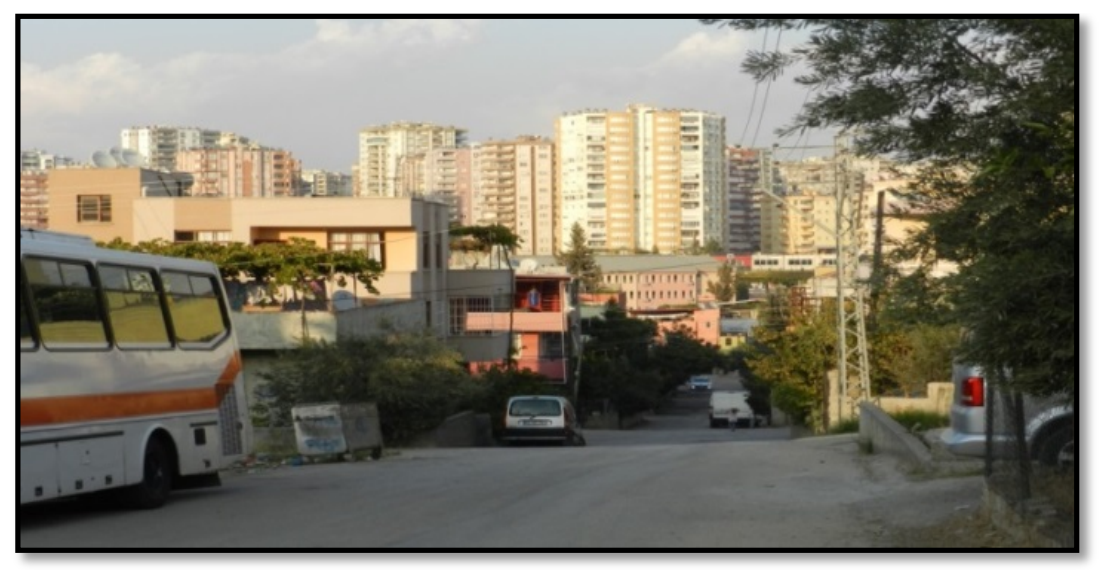

Photo 6. The building complexes surrounding the detached houses in Belediye Evleri. 


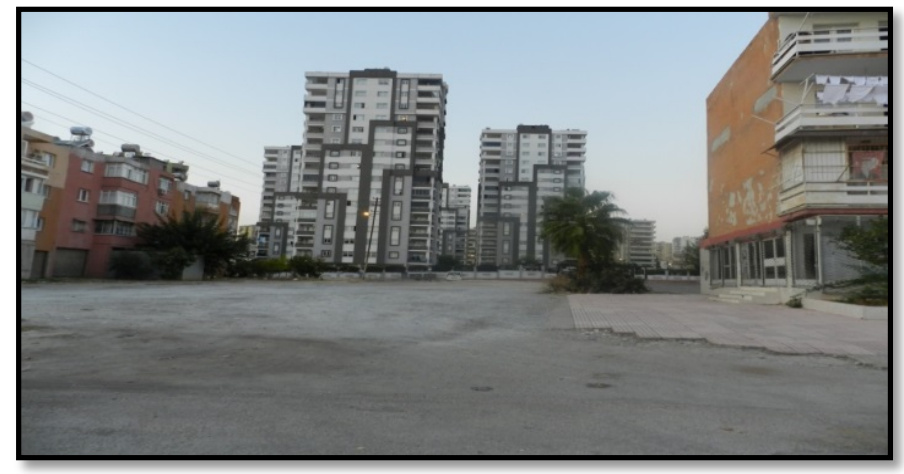

Photo 7. The building complexes surrounding the mass houses in Belediye Evleri.

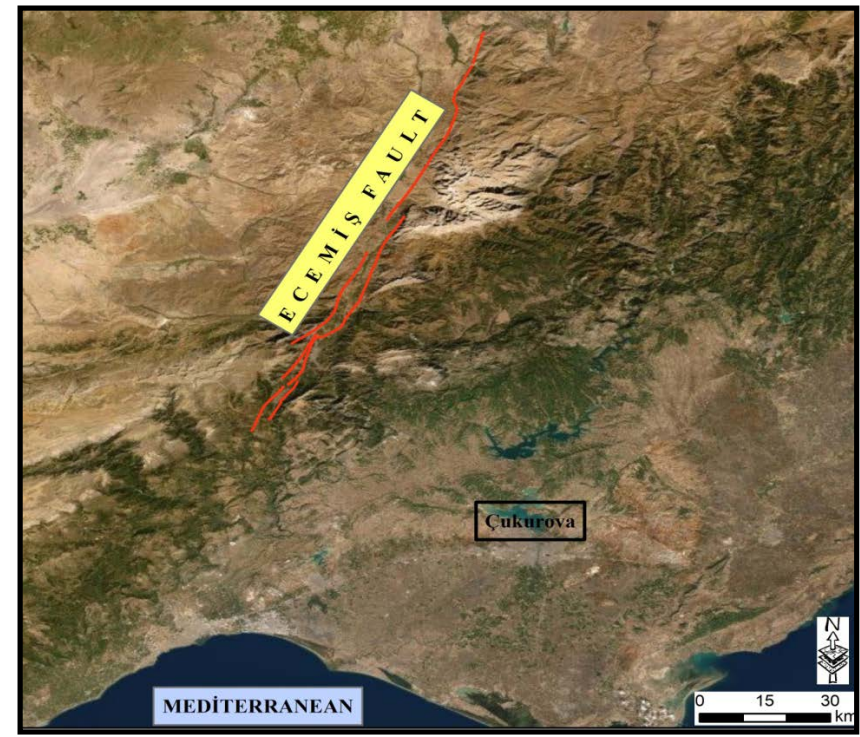

Figure 4. Google earth map view of the Ecemiş Fault.

In addition to lack of social equipment and earthquake risk, this area has worn buildings and social texture. Therefore, an urban transformation not only about new buildings but also about better infrastructure, social and urban equipment had come to the agenda. Existing problems should be taken into consideration and suggestions and solutions should also be given

(http://yenibelediyeevleri.com/).

The project planned for Belediye Evleri is implemented by Çukurova Municipality. The law allowing this transformation to happen was published in the Official Gazette dated 18.05.2013 and numbered 28,651. The law on the urban transformation of Belediye Evleri neighborhood, "The Law on the Transformation of Disaster Risk Areas numbered 6306", was announced by the Council of Ministers' decree numbered 2013/4636 and dated 22.04.2013. In the project site, Urban Transformation Liaison Office was opened in December 2013 and still provides service. The urban transformation software has been established by Çukurova Municipality in order to carry out the reconciliation process with the right holders and the right holders 2 information and documents were digita- 
lized. In addition, the website http://www.yenibelediyeevleri.com/ was activated, and citizens were provided with information. Based on the property records, the owners of 2.213 parcels were checked according to the proofs of ownership, transferred to practices, associated with real estate, right holders were informed, and household and trade surveys were conducted. In the area, 2833 buildings and 7294 independent flats' real estate assessments were made and street fair prices were determined to determine the goodwill groups in the lot stage. These were approved by the General Directorate of Spatial Planning of the Ministry of Environment and Urbanization in March 2017 (http://yenibelediyeevleri.com/ Çukurova Municipality Web Site) (Figure 5).

With this project, in addition to building 15 - 20 storey smart buildings, green areas, schools, playgrounds, large streets and boulevards are said to create a new living space. Today, the belediye Evleri are made up of two sections: 3 - 4-storey houses consisting of residential houses made by the Municipality of Adana, and

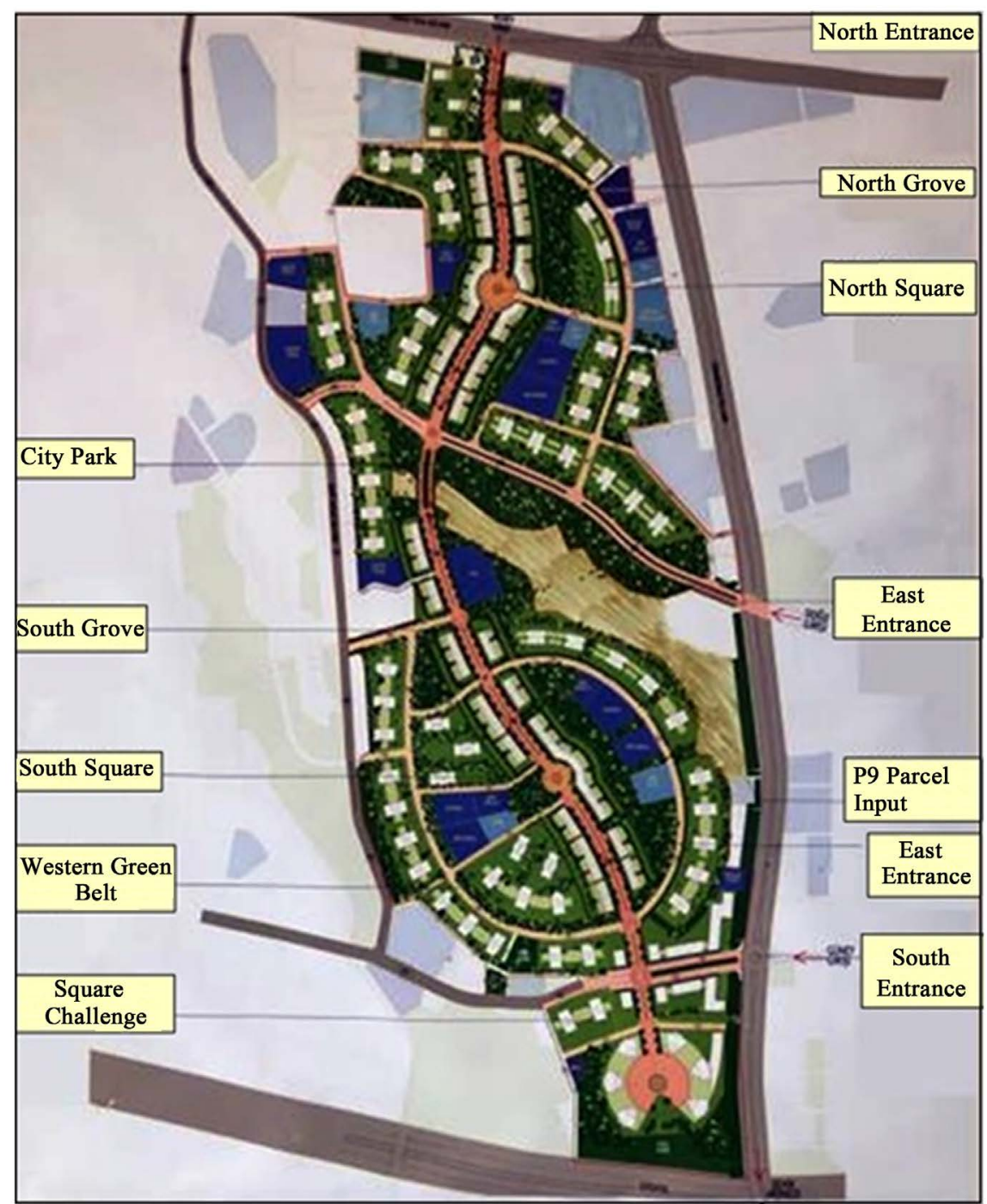

Figure 5. Çukurova Belediye Evleri urban transformation project plan. 
1 - 2-storey detached houses to the east of the mass houses. In the project, it is aimed to build 15 - 20 storey apartment houses based on boulevard, avenue and street system. The residences that had been built by the Metropolitan Municipality were for low-income people and were $60 \mathrm{~m}^{2}$. It is stated that in the new houses to be constructed, they will give apartments to the right holders according to the floor density. Moreover, each apartment is negotiated individually with the owner. The floor densities in the project vary according to the boulevard, avenue and street. Living in $60 \mathrm{~m}^{2}$ houses, residents in the houses built by the metropolitan municipality express that they have to pay money in order to buy a small apartment of $60 \mathrm{~m}^{2}$. Since the houses and land shares of the people living in detached houses and duplex apartments in Belediye Evleri Neighborhood are expensive there are no problems in this section of the neighborhood. However, some of the residents do not want to live in apartment buildings. With the construction of the project, the residents of $60 \mathrm{~m}^{2}$ will either pay the difference for the new flat or take the flat money and buy a suitable home from another location.

\section{Analysis and Evaluation of Urban Transformation Surveys}

The following data was obtained when the surveys on the urban transformation conducted in the housing units of the Belediye Evleri neighborhood's mass houses and detached houses were analyzed. In the survey, the city of Adana constituted the universe, whereas the residents of the Çukurova Central District's Belediye Evleri neighborhood constituted the sample. For this purpose, surveys were applied to a total of 400 people, 200 form mass houses and 200 from detached houses, and their comparisons were made. The percentages of these results were interpreted. This survey reflects the views of the residents of the neighborhood about urban transformation. The views of the people living in the urban transformation space have been put forth based on the geographical analysis made (Tables 1-9).

According to Table 2, the birth place of $70 \%-80 \%$ of the residents of mass houses and detached houses was Adana and its districts. The remaining 20\% $30 \%$ are from the cities around Adana and from Southeastern Anatolia.

According to Table 3, 45\% of the residents in Belediye Evleri Neighborhood's mass houses are high school graduates, 25\% are elementary school graduates, whereas $51 \%$ of the residents in Belediye Evleri Neighborhood's detached houses

Table 2. Birth places of the residents living in Belediye Evleri mass houses and detached houses.

\begin{tabular}{ccc}
\hline Birth Place & Belediye Evleri Mass Houses (\%) & Detached Houses (\%) \\
\hline Adana & 39 & 50 \\
Adana Districts & 34 & 38 \\
Out of Adana & 27 & 12 \\
\hline
\end{tabular}


Table 3. Education status of the residents living in Belediye Evleri mass houses and detached houses.

\begin{tabular}{ccc}
\hline Education Status & Belediye Evleri Mass Houses (\%) & Detached Houses (\%) \\
\hline Graduate & 2 & - \\
Undergraduate & 8 & 5 \\
Two-Year College & 12 & 40 \\
High School & 45 & 51 \\
Elementary School & 25 & 4 \\
Literate & 8 & \\
\hline
\end{tabular}

Table 4. Professions of the residents living in Belediye Evleri mass houses and detached houses.

\begin{tabular}{ccc}
\hline Profession & Belediye Evleri Mass Houses (\%) & Detached Houses (\%) \\
\hline Public Servant & 13 & 2 \\
Engineer & 1 & - \\
Shopkeeper & 14 & - \\
Nurse & 1 & 25 \\
Worker & 29 & 3 \\
Student & 1 & 18 \\
House Wife & 14 & 5 \\
Unemployed & 5 & 29 \\
Retired & 22 & \\
\hline
\end{tabular}

Table 5. Income levels of the residents living in Belediye Evleri mass houses and detached houses.

\begin{tabular}{ccc}
\hline Income Level & Belediye Evleri Mass Houses (\%) & Detached Houses (\%) \\
\hline $500-1000$ & 10 & 5 \\
$1001-1500$ & 21 & 27 \\
$1501-2000$ & 33 & 35 \\
$2001-2500$ & 26 & 24 \\
$2501-3000$ & 5 & 6 \\
$3001-3500$ & 5 & 3 \\
\hline
\end{tabular}

Table 6. The reason why the residents chose the Belediye Evleri neighborhood to live in.

\begin{tabular}{ccc}
\hline Reason to Choose the Neighborhood & Belediye Evleri Mass Houses (\%) & Detached Houses (\%) \\
\hline Economic Necessity & 36 & 30 \\
Appropriateness to Living Conditions & 29 & 29 \\
Known Environment & 26 & 26 \\
Being from the Same Hometown & 4 & 11 \\
Others & 5 & 4 \\
\hline
\end{tabular}


Table 7. Views of the residents living in Belediye Evleri mass houses and detached houses on the buildings' earthquake resistance.

\begin{tabular}{|c|c|c|}
\hline $\begin{array}{l}\text { My building is } \\
\text { earthquake resistant }\end{array}$ & Belediye Evleri Mass Houses (\%) & Detached Houses (\%) \\
\hline Strongly Disagree & 54 & 43 \\
\hline Disagree & 13 & 10 \\
\hline Unsure & 11 & 16 \\
\hline Agree & 17 & 20 \\
\hline Strongly Agree & 5 & 11 \\
\hline
\end{tabular}

Table 8. When planning and constructing the houses of the people, new flats will be given considering everyone's land and apartment size.

\begin{tabular}{ccc}
\hline $\begin{array}{c}\text { Instead of the Belediye Evleri houses I live, } \\
\text { new flats will be given considering everyone's land } \\
\text { and apartment size during urban transformation. }\end{array}$ & $\begin{array}{c}\text { Belediye Evleri } \\
\text { Mass Houses (\%) }\end{array}$ & $\begin{array}{c}\text { Detached } \\
\text { Houses (\%) }\end{array}$ \\
\hline $\begin{array}{c}\text { Strongly Disagree } \\
\text { Disagree }\end{array}$ & 37 & 54 \\
Unsure & 22 & 22 \\
Agree & 19 & 18 \\
Strongly Agree & 20 & 3 \\
\hline
\end{tabular}

Table 9. During the urban transformation of Belediye Evleri mass houses and detached houses, the participation of property owners will be ensured, and their views will be asked.

\begin{tabular}{ccc}
\hline $\begin{array}{c}\text { The participation of property owners will be ensured, } \\
\text { and their views will be asked Belediye Evleri }\end{array}$ & $\begin{array}{c}\text { Belediye Evleri } \\
\text { Mass Houses (\%) }\end{array}$ & $\begin{array}{c}\text { Detached } \\
\text { Houses (\%) }\end{array}$ \\
\hline Strongly Disagree & 35 & 43 \\
Disagree & 17 & 25 \\
Unsure & 30 & 22 \\
Agree & 15 & 7 \\
Strongly Agree & 3 & 3 \\
\hline
\end{tabular}

are elementary school graduates and $50 \%$ of them are high school graduates. In general, the residents are graduates of elementary schools and high schools. However, there are only a few university graduates.

According to Table 4, 29\% of the residents in Belediye Evleri Neighborhood's mass houses are workers, $22 \%$ are retired, $14 \%$ are shopkeepers and $\% 14$ of them are house wives, whereas $29 \%$ of the residents in Belediye Evleri Neighborhood's detached houses are retired, $25 \%$ are workers, $18 \%$ are shopkeepers and $18 \%$ are house wives. The results show that while many of the residents of Belediye Evleri Neighborhoods work in general jobs, only a small number of them work in jobs requiring expertise and technicality. 
According to Table 5, the income of $21 \%$ of the residents in Belediye Evleri Neighborhood' mass houses 1000 - 1500 Turkish Liras, the income of $33 \%$ is 1500 - 2000 Liras, income of $26 \%$ is 2000 - 2500 Liras, whereas the income of $27 \%$ of people living in detached houses is 1000 - 1500 Liras, income of $35 \%$ is 1500 - 2000 Liras, and income of $24 \%$ is 2000 - 2500 Liras. Both of the groups are made up of middle-income and low-income families. Although all might not have stated the truth about their income status, it is apparent that their income levels are below average.

According to Table 6, 36\% of the residents in Belediye Evleri Neighborhood's mass houses gave economic necessity as the reason why they chose to live in the neighborhood, $29 \%$ gave appropriateness to living conditions, $26 \%$ gave knowing the environment, whereas $30 \%$ of the residents living in detached houses gave economic necessity as the reason, $29 \%$ gave appropriateness to living conditions and $26 \%$ gave knowing the environment. The common points of the residents in both sections of the neighborhood are their economic necessities and knowing each other from the same environment.

Table 7 shows that $54 \%$ of the residents in Belediye Evleri Neighborhood's mass houses strongly disagreed that their buildings are earthquake resistant, $17 \%$ agreed, $11 \%$ was unsure and $13 \%$ disagreed. On the other hand, $43 \%$ of the residents in detached houses strongly disagreed that their buildings are earthquake resistant, $20 \%$ agreed, $16 \%$ was unsure, and approximately $21 \%$ stated that their buildings were not earthquake-resistant. As it is understood from the answers given to this question in general, the majority believes that their houses are earthquake resistant.

When the residents living in the Belediye Evleri's mass houses were asked the question "When planning and constructing the houses of the people, new flats will be given considering everyone's land and apartment size" $37 \%$ of them marked strongly disagree, $22 \%$ of them marked disagree, $19 \%$ marked unsure. $54 \%$ of the people living in detached houses marked strongly disagree, $22 \%$ marked, $18 \%$ marked unsure. As it is understood from the surveys, residents living in both of the sections have great hesitation about getting an apartment in the size of their own land and apartment.

When the residents living in the Belediye Evleri's mass houses were asked the question "During the urban transformation of Belediye Evleri mass houses and detached houses, the participation of property owners will be ensured, and their views will be asked", $35 \%$ of them marked strongly disagree, 17\% marked disagree, 30\% marked unsure and 15\% marked agree. On average, 52\% of the respondents were non-respondents, while $30 \%$ were non-respondents. $43 \%$ of the residents of detached houses marked strongly disagree, 25\% marked disagree and $22 \%$ marked unsure. Those who do not participate come to the forefront with a total percentage of $68 \%$. Those living in both houses who answered this question in the survey generally think that their opinions will not be asked during the drawing phase of the plan. 


\section{Result and Recommendations}

Although when the urban transformation studies in the world are analyzed, there are many reasons necessitating the transformation, the main reason that necessitates urban transformation in our country is the necessity of especially transforming the slums that were illegally built on public lands. It is a necessity to turn these slums that are inside the city limits but do not have the necessary infrastructure into habitable and sustainable places. In our country, the way in which these projects will be followed in the implementation process is an important problem. Especially in urban areas such as Istanbul where slums turned into new habitable places with urban transformation, urban transformation has been a fearful dream of the low-income population. Although in some places urban transformation projects in Turkey were implemented successfully in urban areas, in some areas they did not reach their purpose. In fact, they turned into places for some people to get unearned income.

Our study was focused on Çukurova District's Belediye Evleri neighborhood's urban transformation project, which has been implemented by the Ministry of Environment and Urbanization and the municipality. The study employed a survey to get the views and expectations of the residents. The analysis results of these surveys reveal the concerns mentioned before. Especially the fact that the Belediye Evleri has been established in the most attractive area of Adana today and that the rents of the houses in the surrounding building complexes and apartments are very expensive cause low-income people living here to worry. Our survey confirms these concerns since this is not a place where slums were built on public lands or where slums were built unplanned. Completed all its feasibility reports by the Adana Metropolitan Municipality in 1988-1989, Belediye Evleri was built legally by the municipality and sold to its current residents as zoned lands. The public housing flats are quite small, and the residents were able to buy them according to their income level because their socio-economic status was not good. However, since the residents could not make the maintenance and repair of the buildings until they paid for these houses, the buildings were worn and had a very bad appearance. With newly built building complexes and apartments around them, these houses show a bad appearance, particularly amongst these new buildings. However, the houses are still habitable and sustainable. It has a crowded population and daily life is alive. Just repairing the buildings and making them healthier will be enough. The viability and sustainability of the neighborhood continues in daily life.

According to the survey answers of the people living in Belediye Evleri mass housing and single-detached houses, the income level of the residents was below the Turkey average. It was revealed that they would not pay any money while buying their houses in Urban Transformation. They expressed this in interviews. It is seen that the ratio of people working in general fields is high and the ratio of those working in jobs that require expertise and technical knowledge is low in the Belediye Evleri. The common point of the residents living in both types of 
houses is that the neighborhood is economically feasible and that they know each other from the same environment. It is evident from the surveys that the residents of both types of houses in the Belediye Evleri Neighborhood report that their houses are earthquake resistant. As it is understood from the interviews and surveys, the residents expressed great concern that they will receive an apartment based on the size of their plots and apartments. The residents were asked about the municipality allowing them to participate to the urban transformation process. $68 \%$ believed that their participation will not be ensured. The residents of both housings believe that their views will not be taken during the drawing phase of the Project. Today, plans have been made, plot sizes and how many floors and widths of houses were drawn and determined. It is stated in the interviews by the participants and the municipality that the width of the flats is classified by the municipality in addition to the state intervention. The surveys conducted and the choices given to the property owners are parallel. In developed countries, opinions of experts such as lawyers, economists and architects are asked when making plans. This was not done here and also the property owners' opinions were not taken. The municipality itself determined the size of the land, floor and apartment at the drawing stage of the plan and passed the plan to the Ministry of Environment and Urbanization and received the approval for the construction of the project.

All of the Belediye Evleri in the Belediye Evleri Neighborhood were built as zoned, approved, earthquake resistant, and then delivered to their owners. The width and size of the detached houses in the Belediye Evleri Neighborhood were approved by the Adana Metropolitan Municipality, and they were allowed to be built and were large enough for the family size of the landlord. However, these detached houses start from the back of Çukurova Municipality and are located between the new building blocks and apartments. As it is said by the Çukurova Municipality and the neighborhood representative, these detached houses within the building blocks spoil the appearance of the district. However, since Çukurova Municipality wants to take this place also under urban transformation, it does not provide much infrastructure services here. Therefore, the residents expressed their concern that they did not know what to do in the interviews.

Since Belediye Evleri Neighborhood is in the preparation stage of urban transformation, the urban transformation should be supported by taking into consideration the concerns and fears of the residents. However, it should not be forgotten that the income of neighborhood residents should be taken into consideration while this urban transformation is being carried out because the urban transformation plan prepared by the municipality will increase the rent in the neighborhood and this will increase the cost of living in the neighborhood and will not accommodate the minimum wage and retired income groups within the neighborhood. Therefore, Çukurova Municipality, which will implement the Belediye Evleri Urban Transformation Project, is required to continue this project, taking into account the expectations and fears of the residents, away from unearned 
income concerns. To this end, from the next stage of the urban transformation project, the acting of the municipality with the representatives of the residents of the neighborhood will increase the chances of the success of the project and the contribution of the neighborhood to the urban transformation. Moreover, it should be taken into consideration that no additional money should be demanded from the residents who live at $60 \mathrm{~m}^{2}$ in the housing units of the Belediye Evleri mass houses, and that the houses should be for socio-economic structure. Otherwise, these people whose socio-economic status is below the average will not be able to live here and will rebuild the places with low socio-economic structure elsewhere.

\section{Conflicts of Interest}

The author declares no conflicts of interest regarding the publication of this paper.

\section{References}

Akıncı, M. (2007). Ídare, Ínsan Hakları ve Planlama Hukuku. İstanbul: Maltepe Üniversitesi Hukuk Fakültesi Dergisi.

Arslan, H. (2014). Kentsel Dönüşüm Süreçlerinin Kentsel Haklar Temelinde Değerlendirilmesi Gerekliliği. KMÜ Sosyal ve Ekonomik Araştırmalar Dergisi, 16, 33-41. https://doi.org/10.18493/kmusekad.01749

Aydınlı, H. İ., \& Kaya, A. (2013). Yargı Kararları Örnekleri İle Türkiye'de Kentsel Dönüşüm Uygulamalarının Sorun Alanları. In Afyon Kocatepe Üniversitesi, İIBF Dergisi (C. XV, S. II) (pp. 449-467). Afyonkarahisar. https://dergipark.org.tr/tr/download/article-file/18856

Fischel, W. A. (2000). Zoning and Land Use Regulation. In Encyclopedia of Law and Economics (Vol. 2, pp. 403-423). Cheltenham: Edward Elgar.

https://books.google.com.tr/books?id=3XrGDgAAQBAJ\&pg=PA120\&dq=Fischel

Göksu, F. (2003) Kentsel Dönüşüm Projelerine Yenilikçi Yaklaşımlar, Kentsel Dönüşüm Sempozyumu (pp. 270-279). İstanbul: Yıldız Teknik Üniversitesi.

Hardal, S. (2014). Kentsel Dönüşüm Alanlarına Bir Örnek: Sarıgöl Mahallesi. Bilecik: Basılmamış Yüksek Lisans Tezi, Bilecik Şeyh Edebali Üniversitesi Sosyal Bilimler Enstitüsü Coğrafya Anabilim Dalı.

Haziran (1996). Tarihleri arasında Istanbul'da gerçekleştirilen "Birleşmiş Milletler Insan ... Konferansi (Habitat II)". https://webdosya.csb.gov.tr/db/habitat/editordosya/file/dokumanlar/Istanbul\%20Dekle rasyonu.pdf

Heimlich, R., \& Anderson, W. (2001). Development at the Urban Fringe and Beyond: Impacts on Agriculture and Rural Land. Agricultural Economic Report No. AER-803. https://www.ers.usda.gov/publications/pub-details/?pubid=41364

Janssen-Jansen, L. Spaans, L., \& Van der Ven, M. (2008). New Instruments in Spatial Planning: An International Perspective on Non-Financial Compensation. Amsterdam: IOS Press.

https://repository.tudelft.nl/islandora/object/uuid\%3A5c051f70-96ad-48ae-a85f-d590a $2 \mathrm{c} 42 \mathrm{c} 3 \mathrm{f}$

Kılıç, T., \& Hardal, S. (2015). Kentsel Dönüşüm Sürecinde Yok Olan Mahalle Kültürü: 
Sarıgöl Mahallesi (Şen Mahalle) Örneği. In Türkiye Dördüncü Nüfusbilim Konferansı Tebliğ Metinleri Kitabı (pp. 169-176). Ankara: Nüfus Etütleri Enstitüsü. https://www.academia.edu/35408695/Kentsel_D\%C3\%B6n\%C3\%BC\%C5\%9F\%C3\%B Cm_S\%C3\%BCrecinde_Yok_Olan_Mahalle_K\%C3\%BClt\%C3\%BCr\%C3\%BC_Sar\%C 4\%B1g\%C3\%B61_Mahallesi_\%C5\%9Een_Mahalle_\%C3\%96rne\%C4\%9Fi

Koca, H., \& Karadeniz, V. (2014). Erzincan Ovasında Toki Uygulamaları ve Kentleşme Üzerindeki Etkileri. Doğu Coğrafya Dergisi, 19, 101-128. https://doi.org/10.17295/dcd.74420 https://dergipark.org.tr/tr/pub/ataunidcd/issue/2459/31354

Mills, D. E. (1989). Is Zoning a Negative-Sum Game? Land Economics, 65, 1-12. https://www.jstor.org/stable/3146258?seq=1\#metadata_info_tab_contents https://doi.org/10.2307/3146258

Nelson, R. H. (1977). Zoning and Property Rights: An Analysis of the American System of Land-Use Regulation. Cambridge, MA: MIT Press. https://archive.org/details/ZoningAndP_00_Nels

Öcal, T., \& Çalışkan, V. (2017). Yavuzlar (Yüreğir-Adana) Mahallesi Kentsel Dönüşümü İle Toki Konutlarının Karşılaştırmalı Analizi. Marmara Coğrafya Dergisi, Temmuz Sayl, 36, 147-161. https://dergipark.org.tr/tr/pub/marucog/issue/30253/329068

Özsoy, A. (2012). Toplu Konut Uygulamalarının Gelişimi-Bir Değerlendirme. Ekolojik Yapılar ve Yerleşimler Dergisi, 3, 42-46. https://dergipark.org.tr/tr/pub/ataunidcd/article/31354

Pogodzinski, J. M., \& Sass, T. R. (1990). The Economic Theory of Zoning: A Critical Review. Land Economics, 66, 294-314. https://doi.org/10.2307/3146731 https://econpapers.repec.org/article/uwplandec/v_3a66_3ay_3a1990_3ai_3a3_3ap_3a2 94-314.htm

Rydin, Y. (1993). The British Planning System. London: Macmillan. https://doi.org/10.1007/978-1-349-22823-2 https://books.google.com.tr/books?hl=tr\&lr=\&id=skldDwAAQBAJ\&oi=fnd\&pg=PR11 \&dq=Rydin, + Y.+(1993

Rydin, Y. (1998). Land Use Planning and Environmental Capacity: Reassessing the Use of Regulatory Policy Tools to Achieve Sustainable Development. Journal of Environmental Planning and Management, 41, 749-765. https://doi.org/10.1080/09640569811407 https://www.tandfonline.com/doi/abs/10.1080/09640569811407

Shahab, S., Clincha, J. P., \& O’Neilla, E. (2018). Timing and Distributional Aspects of Transaction Costs in Transferable Development Rights Programmes. Habitat International, 75, 131-138. http://www.elsevier.com/locate/habitatint https://doi.org/10.1016/j.habitatint.2018.03.006

Shahab, S., Clincha, J. P., \& O’Neilla, E. (2019). An Analysis of the Factors Influencing Transaction Costs in Transferable Development Rights Programmes. Ecological Economics, 156, 409-419. https://doi.org/10.1016/j.ecolecon.2018.05.018 https://ideas.repec.org/a/eee/ecolec/v156y2019icp409-419.html

Sırma, R. T., \& Çaçtas Ceylan, E. (2009). Gecekondu Alanlarında Kentsel Dönüşüm Uygulamasına Bir Örnek: Küçükçekmece/Ayazma-Tepeüstü Kentsel Dönüşüm Projesi. Çağdaş Yerel Yönetimler, 3, 23-51.

https://docplayer.biz.tr/5944922-Gecekondu-alanlarinda-kentsel-donusum-uygulamasi na-bir-ornek-kucukcekmece-ayazma-tepeustu-kentsel-donusum-projesi.html

Spaans, M., Janssen-Jansen, L., \& van der Veen, M. (2011). Market-Oriented Compensation Instruments: Lessons for Dutch Urban Redevelopment. TPR: Town Planning Review, 82, 425-440. https://doi.org/10.3828/tpr.2011.25 
Tekeli, İ. (2001). Modernite Asılırken Kent Planlaması. Ankara: İmge Kitabevi.

Wang, H., Tao, R., Wang, L., \& Su, F. (2010). Farmland Preservation and Land Development Rights Trading in Zhejiang, China. Habitat International, 34, 454-463. https://doi.org/10.1016/j.habitatint.2009.12.004

http://www.refleksgazetesi.com/cukurova-daki-kentsel-donusum-jeoloji-muhendislerinin -kadrajinda/4888

http://yenibelediyeevleri.com/ 